\title{
PENDAPAT PEMILIK USAHA-USAHA KULINER DI JAKARTA TERHADAP PERAN GO-FOOD DALAM PENGEMBANGAN USAHANYA
}

\author{
Octarini \\ Program Studi Magister Manajemen Universitas Tarumanagara \\ octarinisalim83@gmail.com \\ Eko Harry Susanto \\ Program Studi Magister Manajemen Universitas Tarumanagara
}

\begin{abstract}
The rapid change of technology has a massive impact in all kinds of culinary business in Jakarta. This research will describe opinions from culinary businesses in Jakarta regarding the existence of Go-Food as a tool to develop their business. What role does GoFood play as a tool for their business strategy, the changes they experience after they cooperate the business with Go-Food, and what are their opinions about the best strategy for their cooperation to achieve maximum benefits for every party. This research is using a qualitative descriptive method. The results of this research shows that Go-Food does not bring many influences for well established businesses that had been around for many years, on the contrary in new businesses Go-Food bring a massive impact. Some changes are positive and some are negative. The positive sides are growth of profit and turnover, expanding product delivery range, brand awareness and brand exposure. The negative side is the increases of product price appeared in Go-Food application. At the end of this research every party agree that Go-Food has given a good service for its customers and all culinary businesses whom Go-Food has collaborated with.
\end{abstract}

Abstrak : Kecepatan perubahan teknologi sangat berpengaruh terhadap usaha kuliner di Jakarta. Penulis ingin mengetahui pendapat pemilik usaha kuliner di Jakarta terhadap peran aplikasi Go-Food bagi pengembangan usahanya. Bagaimana strategi masing-masing usaha dalam memanfaatkan Go-Food, perubahan-perubahan yang dialami oleh usaha-usaha kuliner setelah bekerjasama dengan Go-Food dan hal-hal yang ingin dicapai dikemudian hari dari kerjasama ini. Penelitian karya ilmiah ini menggunakan metode kualitatif deskriptif. Hasil penelitian menyatakan bahwa bagi usaha-usaha kuliner yang sudah mapan, Go-Food tidak berperan penting dalam pengembangan usahanya. Sebaliknya bagi usaha kuliner yang baru berdiri Go-Food berperan sangat penting. Perubahan semenjak bekerjasama cukup banyak. Beberapa diantaranya positif dan negatif. Perubahan positif diantaranya kenaikan penjualan, brand awareness dan brand exsposure, serta meluasnya jangkauan pengantaran produk. Hal negative yaitu harga makanan dinaikan lebih mahal dari gerai. Terakhir, hampir semua pihak yang diwawancara dalam penelitian ini menyatakan bahwa Go-Food sudah memberikan pelayanan yang baik bagi pelanggan maupun usaha-usaha kuliner di Jakarta.

\section{Latar belakang}

Beberapa tahun ini usaha kuliner di kota-kota besar khususnya di Jakarta, mengalami peningkatan yang signifikan. Hal ini dapat dilihat dari data menurut kementrian perindustrian. Di tahun 2016 tercatat pertumbuhan industri makanan dan minuman telah tumbuh sebesar 8,5\% dan di tahun 2017 menurut kontan.co.id, Kemprin memprediksi pertumbuhan makanan dan minuman akan naik sebesar 7,5\%. Tercatat Berdasarkan sumber laporan statistik dari SWA, intensitas masyarakat Indonesia yang makan di luar rumah dari tahun 2008-2013 meningkat hinga 250\%. Keberadaan telpon genggam pintar atau 
smartphone, juga memampukan orang-orang melakukan banyak hal diantaranya memesan makanan melalui aplikasi online atau memfoto dan mengunggahnya di media sosial yang berdampak pada promosi makanan dan meningkatkan penjualan makanan tersebut. Sejalan dengan semakin berkembangnya usaha kuliner di Jakarta, usaha ojek online pun saat ini berkembang dengan pesat. Kedua usaha ini saling mendukung satu dengan yang lain. Tidak semua usaha kuliner memiliki jasa delivery atau antar makanan dan jika mereka memiliki jasa delivery, radius yang dapat ditempuh dalam proses pengantaran makanan cukup terbatas. Kekurangan ini dapat diatasi dengan adanya layanan ojek online. Dengan kondisi jalanan Jakarta yang macet dan banyak gang-gang kecil, ojek online memudahkan pemesan makanan agar tidak perlu membuang waktu di perjalanan dan antri untuk mendapatkan makanan yang mereka inginkan bahkan sampai jarak tempuh yang jauh dan jalan-jalan sempit yang sulit dijangkau transportasi lain. Di era teknologi ini, dalam menjawab besarnya kebutuhan akan ojek maka munculah ojek yang berbasis aplikasi. Jadi dengan adanya aplikasi, para pengguna telepon pintar hanya perlu mengunduh aplikasi dan langsung menggunakan layanan ojek online tanpa harus bertemu muka dengan supir. Sejak keberadaannya tujuh tahun yang lalu hingga saat ini sudah tercatat ada lebih dari 250.000 pengemudi ojek online. Aplikasi ojek online tercatat telah diunduh sebanyak 15 juta kali oleh para pelanggannya.

\section{TUJUAN PENELITIAN}

Melihat perubahan yang begitu cepat di dunia teknologi informasi dan pengaruh perkembangan ojek online terhadap usaha kuliner di Jakarta, penting sekali kita mengetahui lebih dalam mengenai hal-hal ini. Bagaimana cara mengatasi masalah-masalah yang terjadi dalam prosesnya dan memprediksi perubahan apa yang mungkin akan terjadi di masa depan agar berbagai pihak khususnya pihak manajerial dapat mempersiapkan diri dalam menghadapi perubahan tersebut dan mengambil langkah-langkah yang perlu dalam mengembangkan usahanya. Tujuan-tujuan penelitian ini diantaranya adalah: memperoleh gambaran yang lebih mendalam mengenai pendapat para pengusaha kuliner di Jakarta terhadap pengaruh ojek online, menemukan fakta-fakta aktual yang dialami oleh usaha-usaha kuliner setelah bekerjasama dengan aplikasi Go-Food, dan melihat lebih dalam mengenai manfaat kerjasama bagi pihak-pihak yang terkait serta hal-hal yang ingin dicapai ini di kemudian hari.

Penelitian ini akan menggunakan metode kualitatif berdasarkan data aktual. Proses penelitian dilakukan dengan wawancara berbagai pihak informan yang dianggap berperan langsung dalam penelitian ini. Pihak-pihak tersebut diantaranya pemilik/pengelola foodcourt, pengemudi ojek online dan pengguna jasa layanan apikasi online pengantaran makanan.

\section{TINJAUAN PUSTAKA}

Beberapa teori yang digunakan oleh penulis dalam penelitian ini diantaranya adalah sebagai berikut:

"Pola bisnis berbasis pada web atau jaringan internet ini, efekstif dan efisien untuk memasarkan produk-produk yang dijual dengan tampilan semenarik mungkin. Dengan basis internet, model bisnis ini dapat memangkas hambatan geografis dan kultural di masyarakat sebagai konsumen maupun calon konsumen. Wilayah pemasaran juga menjadi semakin luas, tanpa harus mengeluarkan biaya operasional yang besar". Dikutip dari Komunikasi Manusia: Teori dan Praktik Dalam Penyampaian Gagasan.

Dalam jurnal yang berjudul "The effectt of advertising on brand awareness and percieved quality: an emperical investigation using panel data" karya C. Robert Clark, Ulrich 
Doreazselki dan Michaela Draganska (2009:227) terbitan ProQuest mengatakan bahwa konsumen suka menyamakan antara brand awareness dengan preferences. Konsumen biasanya lebih memilih sesuatu yang dianggap paling familiar dengannya, dan ketika konsumen sudah merasa aware terhadap suatu brand belum tentu konsumen memiliki preferensi terhadap brand tersebut. Hal ini sesuai dengan hasil wawancara dengan customer Go-Food yang mengatakan bahwa, walaupun mereka senang melihat banyak pilihan makanan di aplikasi namun pada akhirnya keputusan pemesanan dijatihkan pada restaurant yang mereknya sudah terpercaya dan sudah sering dipesan.

Kutipan dari Buku Karya Kotler dan Keller (2006:180) yang berjudul Manajemen Pemasaran mengatakan tentang Atensi Selektif. Orang cenderung lebih memperhatikan rangsangan yang deviasinya besar dalam hubungannya dengan ukuran normal. Misalnya iklan dengan penawaran potongan harga lima puluh ribu rupiah akan terlihat lebih menarik dari potongan harga yang hanya lima ribu rupiah. Jika harga tinggi, pembeli enggan membeli makanan di restoran tersebut.

Menurut pakar manajemen James Moore Phd Seperti yang dikutip Widioatmodjo (2016:256) dari buku New Business Model in Digital Age:

"Jadi, Jal yang tersirat disini adalah pentingnya kerja sama (diantara mitra bisnis: konsumen, pemasok, bahkan pesaing). Bahkan menurut Moore, dewasa ini banyak bisnis memiliki ide yang melimpah, teknologi yang canggih, atau modal yang banyak. Tapi itu semua tidak menjamin keberlangsungan bisnis, tanpa ada kemampuan menggalang kerja sama diantara stakeholder".

\section{METODOLOGI PENELITIAN}

Metode yang digunakan dalam penelitian ini adalah metode kualitatif. Penelitian kualitatif adalah penelitian tentang riset yang bersifat deskriptif dan cenderung menggunakan analisis. Proses dan makna (perspektif subjek) lebih ditonjolkan dalam penelitian kualitatif. Landasan teori dimanfaatkan sebagai pemandu agar fokus penelitian sesuai dengan fakta di lapangan. Kualitas penelitian dilihat dari seberapa dalam penelitian berhasil memperoleh data. Semakin dalam data dan analisis maka semakin baiklah penelitian. Peneliti ikut masuk ke dalam situasi yang ditelitinya. Data yang sudah dikumpulkan dalam penelitian deskriptif kualitatif selanjutnya akan ditafsirkan sesuai dengan keadaan faktual yang sedang terjadi, bagaimana situasi yang satu mempengaruhi situasi yang lain, dan tanggapan atau sikap masyarakat mengenai hal-hal yang sedang terjadi dan lain-lain. Maka penelitian yang dilakukan oleh penulis adalah mengumpulkan informasi pengalaman mengenai penggunaan teknologi aplikasi ojek online terbaru yang berasal dari proses wawacara lisan pemilik usaha-usaha kuliner di Jakarta, pengguna aplikasi dan pengemudi ojek online terkait dengan hal-hal mengenai penggunaan ojek online dalam perkembangan usaha kuliner.

\section{HASIL DAN KESIMPULAN}

Penulis mewawancara lima pengelola usaha kuliner di Jakarta. Usaha-usaha kuliner ini ada yang sudah berdiri sejak lebih dari tiga uluh tahun yang lalu ada pula yang baru berdisi dua tahun. Ada yang memiliki cabang di seluruh Indonesia namun ada pula yang berskala kecil dengan memiliki gerai di kawasan kaki lima. Semua informan bekerjasama dengan aplikasi Go-Food. Usaha-usaha kuliner yang diwawancara adalah restoran Warung Tekko, Bakmi Aloi, Kebab Turki Baba Rafi, Kantin Kebi-Kebi dan Soto Suko Marem. Selain itu penulis juga mewawancara empat pengguna Go-Food yang berasal dari berbagai kalangan masyarakat dan tiga pengemudi Go-Jek. 
Berdasarkan hasil penelitian yang dilakukan oleh penulis maka kesimpulan yang didapat adalah sebagai berikut.

Go-Food hanyalah strategi tambahan bagi usaha-usaha kuliner yang sudah lama berdiri dan sudah memiliki merek yang mapan. Dapat dilihat dari beberapa restoran yang sudah berdiri lebih dari sepuluh tahun yaitu restoran Warung Tekko, Bakmi Aloi, Kantin Kebi-kebi dan Soto Suko Marem bahwa bahkan sebelum ada Go-Food, restoran ini sudah bertahan dan berhasil mengembangkan usahanya dengan mengandalkan strategi-strategi konvensionalnya sediri misalnya dengan menciptakan rasa yang unik, menjaga kualitas bahan baku dan selalu ramah terhadap pelanggan. Keberadaan Go-Food tidak terlalu mempengaruhi penjualan restoran-restoran ini dan hanya bersifat membantu pemasaran online dan pengantaran saja. Keberadaan restoran-restoran yang sudah lama ini ditopang oleh loyalitas pelanggan yang sudah memiliki kepercayaan terhadap merek yang sudah lama ada. Pemilik usaha tidak mengkhawatirkan penjualan dari Go-Food karena lebih mengutamakan prlanggan yang loyal yang datang setiap hari ke gerai restoran mereka.

Bagi restoran yang baru berdiri, Go-Food memberi banyak bantuan kemudahan pemasaran. Diambil dari contoh Kebab Turki Baba Rafi yang enam puluh persen penjualannya berasal dari Go-Food. Karena sebuah usaha yang baru dibangun memerlukan promosi yang lebih banyak dan gencar maka dibutuhkan suatu media yang efektif. Keterbatasan modal untuk promosi dapat diatasi dengan adanya Go-Food dengan sistem pembagian hasil yang cukup efisien.

Era pemasaran melalui teknologi media komunikasi digital sudah tidak dapat dihindari, bahkan oleh pedagang kaki lima sekalipun karena efeknya yang sangat luas. Jika teknologi pemasaran melalui media digital dapat dimanfaatkan dengan baik maka siapapun dapat memperoleh keuntungan yang besar. Aplikasi Go-Food yang sudah menjangkau kawasan yang begitu luas dapat dimanfaatkan dengan mudah oleh siapapun. Ketersediaan produk makanan yang mudah diakses di telpon pintar memberikan kemudahan bagi pelanggan dimana saja mereka berada. Teknologi pembayaran tanpa uang tunai juga dinilai sangat efisien menurut semua pihak yang diwawancara oleh penulis.

Go-Food berhasil meningkatkan penjualan semua restoran yang sudah diwawancara oleh penulis. Selain itu Go-Food juga meningkatkan brand awareness dan brand exposure, memperluas jangkauan penjualan dan dari hasil wawancara dapat disimpulkan pula bahwa hampir tidak ada keluhan dari pelangan Go-Food. Hal ini menunjukan bahwa pelanggan cukup puas dengan pelayanan yang diberikan Go-Food selama ini. Hal yang dianggap negatif hanyalah keharusan pemilik restoran untuk menaikan harga penjualan karena harus membagi hasil dengan Go-Food. Dilihat dari hasil wawancara, seluruh informan berpendapat bahwa pengaruh positif Go-Food lebih banyak dari pengaruh negatifnya.

\section{DAFTAR PUSTAKA}

Kotler, Philip. Keller, Kevin Lane (2009): Manajemen Pemasaran, Edisi Ketiga belas. Jakarta: Erlangga.

Susanto, Eko H (2018). Komunikasi Manusia: Teori dan Praktik Dalam Penyampaian Gagasan. (Edisi 1). Jakarta: Mitra Wacana Media

Moleong, Lexy J, (2017), Metedologi Penelitian Kualitatif edisi Revisi, Penerbit Rosda.

Widoatmodjo, Sawidji. (2016). New Business Model In Digital Age, Edisi 1. Jakarta: PT Alex Media Komputindo, Kompas Gramedia

Bohang, Fatimah K, Berapa Jumlah Pengguna dan Pengemudi Go-Jek? (2017), diakses pada 5 Januari 2018, https://tekno.kompas.com/read/2017/12/18/07092867/berapa-jumlahpengguna-dan-pengemudi-go-jek

Tentang Go-Food dan Go-Resto, 2 Oktober 2017, https://www.go-jek.com/go-food/bisnis\#!/ 
Triwijanarko, Ramadhan (2018), Go-Food Jadi Layanan Pesan Antar Makanan Terbesar di Dunia, diakses pada 12 Maret 2018, http://marketeers.com/go-food-menjadi-layananpesan-antar-makanan-terbesar-di-dunia/

Setiawan, Bambang (2012), Siapa Kelas Menengah Indonesia?, diakses pada 10 April 2018, http://nasional.kompas.com/read/2012/06/08/13003111/Siapa.Kelas.Menengah.Indon esia

Go-jek nyaris untung di semua segmen kecuali transportasi, diakses pada 10 Oktober 2018, https://kumparan.com/@kumparantech/go-jek-nyaris-untung-di-semua-segmenkecuali-transportasi-1534586661975888637

Nugroho, Adam R, Masuk modal besar, Go-Jek kini lebih bernilai daripada Garuda Indonesia. diakses pada 6 Mei 2018, https://kumparan.com/@kumparantech/go-jeknyaris-untung-di-semua-segmen-kecuali-transportasi-1534586661975888637 
